\title{
Fixed-Bed Column Technique for the Removal of Phosphate from Water Using Leftover Coal
}

\author{
Dereje Tadesse Mekonnen ${ }^{1,2}$ (D), Esayas Alemayehu ${ }^{3,4, *}$ and Bernd Lennartz ${ }^{2, *(D)}$ \\ 1 School of Chemical Engineering, Jimma Institute of Technology, Jimma University, \\ Jimma P.O. Box 378, Ethiopia; getdere@gmail.com \\ 2 Faculty of Agricultural and Environmental Sciences, University of Rostock, Justus von-Liebig Weg 6, \\ 18059 Rostock, Germany \\ 3 Faculty of Civil and Environmental Engineering, Jimma Institute of Technology, Jimma University, \\ Jimma P.O. Box 378, Ethiopia \\ 4 Africa Center of Excellence for Water Management, Addis Ababa University, \\ Addis Ababa P.O. Box 1176, Ethiopia \\ * Correspondence: esayas16@yahoo.com (E.A.); bernd.lennartz@uni-rostock.de (B.L.)
}

check for updates

Citation: Mekonnen, D.T.; Alemayehu, E.; Lennartz, B. Fixed-Bed Column Technique for the Removal of Phosphate from Water Using Leftover Coal. Materials 2021, 14, 5466. https://doi.org/ $10.3390 /$ ma14195466

\section{Academic Editors:}

Emmanuel Unuabonah and Andreas Taubert

Received: 15 August 2021

Accepted: 17 September 2021

Published: 22 September 2021

Publisher's Note: MDPI stays neutral with regard to jurisdictional claims in published maps and institutional affiliations.

Copyright: (C) 2021 by the authors. Licensee MDPI, Basel, Switzerland. This article is an open access article distributed under the terms and conditions of the Creative Commons Attribution (CC BY) license (https:/ / creativecommons.org/licenses/by/ $4.0 /)$.

\begin{abstract}
The excessive discharge of phosphate from anthropogenic activities is a primary cause for the eutrophication of aquatic habitats. Several methodologies have been tested for the removal of phosphate from aqueous solutions, and adsorption in a flow-through reactor is an effective mechanism to reduce the nutrient loading of water. This research aimed to investigate the adsorption potential of leftover coal material to remove phosphate from a solution by using continuous flow fixed-bed column, and analyzes the obtained breakthrough curves. A series of column tests were performed to determine the phosphorus breakthrough characteristics by varying operational design parameters such as adsorbent bed height ( 5 to $8 \mathrm{~cm}$ ), influent phosphate concentration (10-25 mg/L), and influent flow rate $(1-2 \mathrm{~mL} / \mathrm{min})$. The amorphous and crystalline property of leftover coal material was studied using XRD technology. The FT-IR spectrum confirmed the interaction of adsorption sites with phosphate ions. Breakthrough time decreased with increasing flow rate and influent phosphate concentration, but increased with increasing adsorbent bed height. Breakthroughcurve analysis showed that phosphate adsorption onto the leftover coal material was most effective at a flow rate of $1 \mathrm{~mL} / \mathrm{min}$, influent phosphate concentration of $25 \mathrm{mg} / \mathrm{L}$, and at a bed height of $8 \mathrm{~cm}$. The maximal total phosphate adsorbed onto the coal material's surface was $243 \mathrm{mg} / \mathrm{kg}$ adsorbent. The Adams-Bohart model depicted the experimental breakthrough curve well, and overall performed better than the Thomas and Yoon-Nelson models did, with correlation values $\left(\mathrm{R}^{2}\right)$ ranging from 0.92 to 0.98 . Lastly, leftover coal could be used in the purification of phosphorus-laden water, and the Adams-Bohart model can be employed to design filter units at a technical scale.
\end{abstract}

Keywords: breakthrough curve; fixed-bed column; bed height; adsorption; eutrophication

\section{Introduction}

Increasing concern about the effect of phosphate released from different natural and human activities has resulted in more stringent environmental policies in recent years. Phosphate is one of the main nutrients for plants and aquatic lives, and is, in turn, primarily responsible for the eutrophication of water [1-6]. The eutrophication of water bodies due to phosphate discharges is a challenging issue for industrialized regions $[7,8]$. Domestic activities, detergent-making industries, and mining companies are the primary sources for phosphate discharged to water bodies. The uncontrolled use of fertilizers also releases phosphate and affects nearby water streams due to the runoff from agricultural activities $[9,10]$. Water pollution by phosphate is tremendously increasing, and demand for the removal of excess phosphate from water bodies is thereby also increasing [11].

There are numerous methods to remove phosphate from water, including chemical precipitation, biological treatment, physical process, coagulation, and adsorption [12-15]. 
Nevertheless, most of them, with the exception of adsorption, show drawbacks due to the high sludge production, the complexity of the process, and high operational costs compared with adsorption methods [16,17]. Adsorption has received immense interest due to its high removal efficiency, simple operation, better cost effectiveness, less or no sludge production, and invulnerability to coexisting pollutants [18-20]. The application of low-cost and locally available materials for phosphate removal was widely investigated during this decade, such as with modified biochar [20], steel slag [21], volcanic rock [22], alkaline Tunisian soil [23], chitosan composite [24], alum sludge [25], and furnace slags [26]

Numerous studies were applied as adsorption methods and to remove phosphate from water by using batch experiments with different low-cost adsorbents [24,27-29]. At the industrial scheme, however, it was difficult to remove phosphate from a large amount of a water solution at the industrial level using batch adsorption [30], so continuous-flow fixed-bed column adsorption is versatile in the removal of phosphate from large amounts of a water solution using low-cost adsorbents [12].

In the present study, phosphate removal potential was examined in a fixed-bed column by using leftover coal material. The same authors verified the application of leftover-coal [31] and volcanic-rock [22] material as potential adsorbents for the recovery of phosphate from an aqueous solution through classical slurry batch experiments. However, batch-adsorption data are inconvenient for large-scale volumes due to the overestimation of sorption capacities [32]. In order to obtain convincing results, fixed-bed column adsorption is more realistic and popular in water treatment plants due to its continuous, high-yield, easy, and economical operation, and the ability to be scaled up from the laboratory scale [33]. Furthermore, few or no studies have reported on the phosphate adsorption capacity of leftover coal via continuous-flow fixed-bed column methods. Therefore, the main objective of this study is to: (i) investigate the application of fixed-bed column for the removal of phosphate using leftover coal material, (ii) study the effects of operational parameters on removal capacity by using breakthrough-curve analysis, and (iii) correlate experimental data with theoretical breakthrough-curve models to predict overall adsorption behaviors.

\section{Materials and Methods}

\subsection{Adsorbent Preparation and Characterization}

The coal material was obtained from Yayu coal mining, as presented in our previous study [31]. Prior to the experiments, the coal material was washed several times using deionized water to remove dust, dirt, and adhering particles from the surface of the adsorbent, and then dried for $24 \mathrm{~h}$ at $105^{\circ} \mathrm{C}$ in an oven dryer. The well-dried materials were ground into a powder form. The ground powder was sieved to the size of $0.075-0.425 \mathrm{~mm}$. The well-prepared adsorbent materials were labeled and stored in desiccator until the following experiments.

Proximate and ultimate analyses of the adsorbent material were performed according to our previous research [31]. The $\mathrm{pH}$ zero point charge ( $\mathrm{pHzpc}$ ) of the adsorbent material was measured according to [34] by using the solid-addition method. The organic matter, moisture content, and pHzpc of the material were measured to be $28.5 \%, 0.93 \%$, and 4.6, respectively.

The functional groups of the adsorbent material were recorded using an FTIR machine (PerkinElmer, FT-IR spectrometer-Spectrum two) in the mid infrared region of $450-5000 \mathrm{~cm}^{-1}$ with a spectral resolution of $2 \mathrm{~cm}^{-1}$. First, the pellet was prepared from dried sample materials by the proper mixing of potassium bromide $(\mathrm{KBr})$ with a 1:9 adsorbent-to- $\mathrm{KBr}$ ratio [35] and ground to a very fine size. The well-mixed material was pelletized using a pressure corporation machine, and the pellets were then measured accordingly [36]; the Fourier transform infrared (FT-IR) of the adsorbent material is shown in Figure 1. 


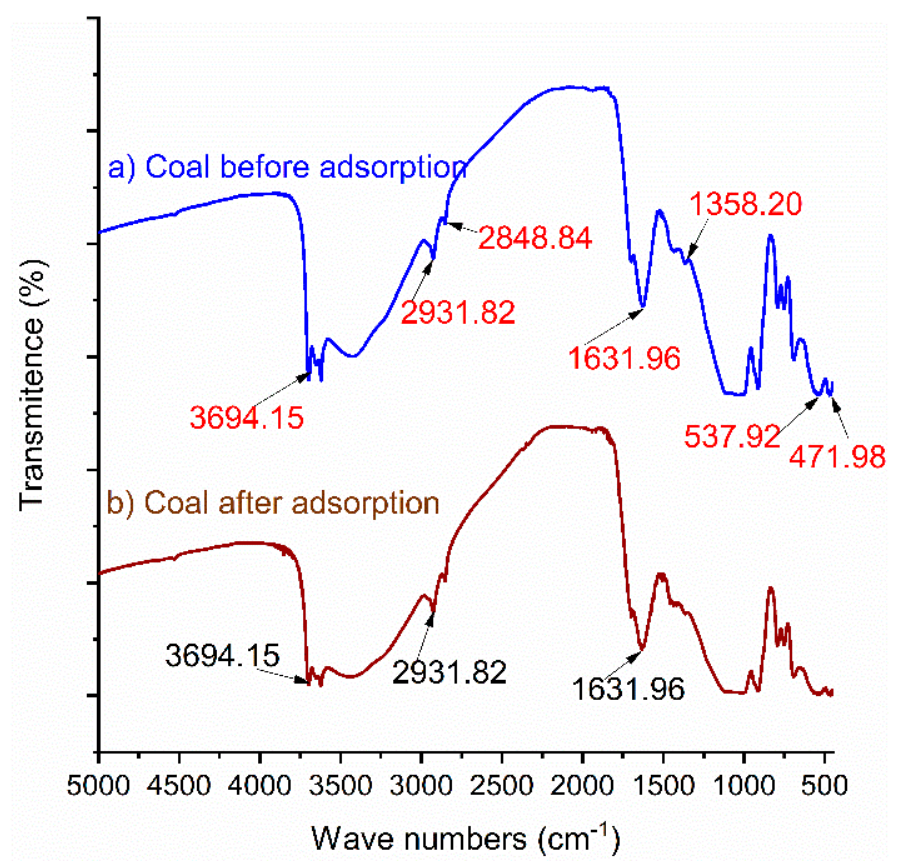

Figure 1. FT-IR results for leftover coal material (a) before and (b) after adsorption.

X-ray diffraction (XRD) analysis was performed to observe the crystal structure and mineral composition of the adsorbents. The XRD patterns of the leftover coal were recorded using an XRD apparatus (XRD-7000, SHIMADZU Corporation, Japan). Before XRD analysis, the leftover coal material was washed, dried in an oven to the appropriate temperature, and milled and sifted through a 75-micrometer sieve to obtain uniform and homogeneous particles. Then, $\mathrm{XRD}$ analysis was recorded with $\mathrm{CuK} \alpha$ as the source radiation at wave length of $1.4 \mathrm{~nm}$, at $40 \mathrm{kV}$ and $30 \mathrm{~mA}$ (Figure 2). All employed chemicals and reagents in this study were of analytical grade unless otherwise specified.

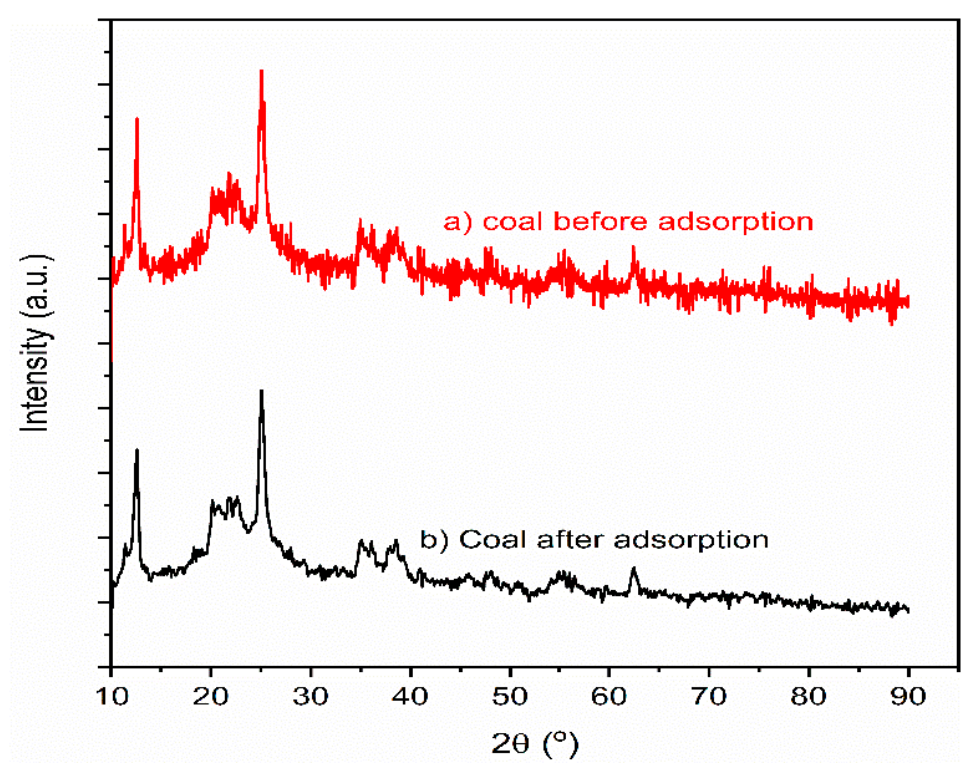

Figure 2. XDR patterns of leftover coal material (a) before and (b) after adsorption.

\subsection{Phosphate Adsorption in a Fixed Bed Column}

The fixed-bed column adsorption experiments were conducted using a Pyrex glass column of $130 \mathrm{~mm}$ height and $26 \mathrm{~mm}$ diameter. The column was packed with a known 
amount of adsorbent material (leftover coal) to achieve the intended bed heights (5 to $8 \mathrm{~cm}$ ), and then caped at the top and at the bottom with glass wool to avoid bed height changes due to the loss of some adsorbents and to prevent adsorbent wash out. Artificial phosphate-laden wastewater was synthesized by previously diluting phosphate stock solution with a concentration of $1000 \mathrm{mg} / \mathrm{L}$ to the working solution at concentrations of 10 to $25 \mathrm{mg} / \mathrm{L}$ using distilled water, and the $\mathrm{pH}$ of each working solution was adjusted to 3.5 using $\mathrm{HCl}$ and $\mathrm{NaOH}$ by $\mathrm{pH}$ meter according to our previous works [22,31]. Depending on the $\mathrm{pH}$ of the working solution, phosphorus can be present in the solution in the form of $\mathrm{H}_{3} \mathrm{PO}_{4}, \mathrm{H}_{2} \mathrm{PO}_{4}{ }^{-}, \mathrm{HPO}_{4}{ }^{2-}$, and $\mathrm{PO}_{4}{ }^{-3}$. At the working $\mathrm{pH}$ of 3.5, dihydrophosphate ion $\left(\mathrm{H}_{2} \mathrm{PO}_{4}^{-}\right)$species was dominating, which can be seen from the repartition or speciation diagram of phosphate ion [37].

Prior to the experiments, the filled and packed column was flushed upward by deionized water until steady flow conditions were established [38]. The working solution then pumped up through the column with different flow rates ( 1 to $2 \mathrm{~mL} / \mathrm{min}$ ) using a peristaltic pump (MS-REGLO, Labortechnik-Analytic, Zurich, Switzerland). In order to obtain the breakthrough curves, the effluent was collected at a predetermined interval of time. Lastly, equilibrium phosphate concentration was measured by continuous flow analyzer (AA3 from Seal analytical GmbH, Norderstedt, Germany).

\subsection{Theory and Column Data Evaluation}

The obtained data from the fixed-bed column studies were used to estimate the breakthrough curve by plotting the $C_{t} / C_{o}$ (the ratio of effluent phosphate concentration at time $t$ to influent phosphate concentration) vs. time. The breakthrough curve, therefore, could be calculated at breakthrough time $\left(t_{b}\right)$ at which the $C_{t} / C_{o}=90 \%$ and exhaustion time $\left(t_{e}\right)$ at which $C t / C o=10 \%$, defined as $C_{t} / C_{o}=0.9$ and $C_{t} / C_{o}=0.1$, respectively. The breakthrough curve and its shape are the main characteristics that are used to investigate the dynamic response of the adsorption system [39]. For a desired initial phosphate concentration and flow rate, the total amount of phosphate retained by the column, $\mathrm{q}_{\text {total }}$ (mg) could be calculated from the area under the breakthrough curve (Equation (1)), while the mass of phosphate adsorbed per mass of adsorbent at equilibrium (qe $(\mathrm{mg} / \mathrm{g})$ ) was calculated from Equation (2) [40].

$$
\begin{gathered}
\mathrm{q}_{\text {total }}=\frac{\mathrm{QC}_{\mathrm{o}}}{1000} \int_{\mathrm{t}=0}^{\mathrm{t}=\text { total }}\left(1-\frac{\mathrm{C}_{\mathrm{t}}}{\mathrm{C}_{\mathrm{o}}}\right) \mathrm{dt} \\
\mathrm{q}_{\mathrm{e}}=\frac{\mathrm{q}_{\text {total }}}{\mathrm{m}}
\end{gathered}
$$

where $\mathrm{Q}$ is the volumetric flow rate $(\mathrm{mL} / \mathrm{min})$, and $\mathrm{m}$ is mass of adsorbent packed within the column $(\mathrm{g})$.

The mass transfer zone (MTZ) is defined as the active region of the coal material where the adsorption of phosphate takes place and can be defined as Equation (3) [41,42].

$$
\mathrm{MTZ}=\mathrm{H}_{\mathrm{b}}\left(\frac{\mathrm{t}_{\mathrm{e}}-\mathrm{t}_{\mathrm{b}}}{\mathrm{t}_{\mathrm{e}}}\right)
$$

where $\mathrm{H}_{\mathrm{b}}$ is total bed height $(\mathrm{cm})$, and $\mathrm{t}_{\mathrm{b}}$ and $\mathrm{t}_{\mathrm{e}}$ are the breakthrough time and exhaustion time ( $\mathrm{min})$, respectively, which can be obtained from the area under the curves (Equations (4) and (5)) [43-45].

$$
\begin{aligned}
& t_{b}=\int_{0}^{t_{b}}\left(1-\frac{C_{t}}{C_{o}}\right) d t \\
& t_{e}=\int_{0}^{t_{\text {total }}}\left(1-\frac{C_{t}}{C_{o}}\right) d t
\end{aligned}
$$


Empty bed contact time (EBCT) is the time of contact between the water phase and the adsorbent (Equation (6)), and it measures critical depth and contact time for the adsorbent [23].

$$
\mathrm{EBCT}=\frac{\mathrm{V}_{\mathrm{b}}}{\mathrm{Q}}
$$

where $\mathrm{V}_{\mathrm{b}}$ is adsorbent bed volume $(\mathrm{mL})$, which can be described as $\left(\mathrm{V}_{\mathrm{b}}=\pi \mathrm{r}^{2} \mathrm{H}_{\mathrm{b}}, \mathrm{H}_{\mathrm{b}}\right.$ is the corresponding bed height in $\mathrm{cm}, \mathrm{r}$ is the inner radius of the bed column tube), and $\mathrm{Q}$ is volumetric flow rate $(\mathrm{mL} / \mathrm{min})$. The total amount of phosphate $\left(\mathrm{P}_{\text {total }}, \mathrm{mg}\right)$ entering the bed can be used to determine the removal efficiency of the column, and can be calculated according to Equation (7) $[9,35,46]$.

$$
\mathrm{P}_{\text {total }}=\frac{\mathrm{QC}_{\mathrm{o}} \mathrm{t}_{\text {total }}}{1000}
$$

where $t_{\text {total }}(\mathrm{min})$ is the operation time for the saturation of the adsorbate. Effluent volume Ve $(\mathrm{mL})$ can also be calculated from the product of flow rate and total time, where influent volume $V_{i}$ is obtained from the product of flow rate and break though time $[19,47]$.

\subsection{Theoretical Breakthrough-Curve Models}

Several theoretical adsorption models have been used to predict the dynamic adsorption behavior of the leftover coal in a fixed-bed column. Therefore, in this work, three of most commonly used mathematical models, the Thomas, Adams-Bohart, and Yoon-Nelson models, were applied.

Thomas model: It is the most widely used theoretical model to evaluate column performance and predict concentration-time profile of the whole breakthrough curve. The model assumes that adsorption is limited by the mass transfer at the interface rather than chemical interactions of the molecules; experimental data obey the Langmuir isotherm and the second-order reversible kinetic model $[10,20]$. The linear form of the Thomas model can be expressed using Equation (8).

$$
\ln \left(\frac{\mathrm{C}_{\mathrm{o}}}{\mathrm{C}_{\mathrm{t}}}-1\right)=\frac{\mathrm{K}_{\mathrm{Th}} \mathrm{q}_{\mathrm{Th}} \mathrm{m}}{\mathrm{Q}}-\mathrm{K}_{\mathrm{Th}} \mathrm{C}_{\mathrm{o}} \mathrm{t}
$$

where $C_{o}$ and $C_{t}$ are influent and effluent phosphate concentration (mg/L), respectively, $\mathrm{K}_{\mathrm{Th}}(\mathrm{mL} / \mathrm{min} . \mathrm{mg})$ is the Thomas rate constant, $\mathrm{q}_{\mathrm{Th}}(\mathrm{mg} / \mathrm{g})$ is predicted adsorption bed capacity, $\mathrm{m}(\mathrm{g})$ mass of adsorbent packed within the column, and $\mathrm{Q}(\mathrm{mL} / \mathrm{min})$ is flow rate. From the plot of $\ln \left(\frac{C_{0}}{C_{t}}-1\right)$ vs. $t$, the values of $K_{T h}$ and $q_{T h}$ can be determined using the slope and intercept, respectively.

Adams-Bohart model: The bed depth service time (BDST) is the other linearized form of Adams-Bohart (A-B) model expression, commonly applied to illustrate the relationship between service time and bed depth at fixed-bed column study [48,49]. The A-B model generally predicts a linear relationship between bed height and the time required to reach breakthrough time [50]. The linear form of A-B model can be expressed by Equation (9) [19,51].

$$
\ln \left(\frac{\mathrm{C}_{\mathrm{t}}}{\mathrm{C}_{\mathrm{o}}}\right)=\mathrm{K}_{\mathrm{AB}} \mathrm{C}_{\mathrm{o}} \mathrm{t}-\mathrm{K}_{\mathrm{AB}} \mathrm{N}_{\mathrm{o}}\left(\frac{\mathrm{H}_{\mathrm{b}}}{\mathrm{U}}\right)
$$

where $\mathrm{K}_{\mathrm{AB}}(\mathrm{L} / \mathrm{mg} \mathrm{min})$ is the Adams-Bohart rate constant, $\mathrm{N}_{\mathrm{o}}(\mathrm{mg} / \mathrm{L})$ is saturation concentration in column (adsorption capacity per unit volume), $\mathrm{H}_{\mathrm{b}}(\mathrm{cm})$ is the column bed height, and $U(\mathrm{~cm} / \mathrm{min})$ is linear velocity and is calculated by dividing $Q(\mathrm{~mL} / \mathrm{min})$ by the cross sectional area $\left(\mathrm{cm}^{2}\right)$ of the bed $\left(\mathrm{U}=\frac{\mathrm{Q}}{\mathrm{A}}\right)$. This model is more appropriate for describing the initial parts of the adsorption breakthrough curve at which $\mathrm{Ct} / \mathrm{Co}=0-0.5[10,41]$. The values of $\mathrm{K}_{\mathrm{AB}}$ and No are determined from the linear plot of $\ln \left(\frac{\mathrm{C}_{\mathrm{t}}}{\mathrm{C}_{\mathrm{o}}}\right)$ vs. $t$, which are equivalent to the slope and intercept of the linear plot, respectively [50].

Yoon-Nelson Model: This theoretical model is based on the assumption that the rate of adsorption for each adsorbate is proportion to the rate of decrease in adsorption. 
The model does not require explicitly elaborated information about the characteristics of adsorbate and its type [52]. It rather predicts $50 \%$ of the breakthrough time and simulate the column data obtained from single adsorbate system [15]. The linear form of the model can be expressed by Equation (10) [48].

$$
\ln \left(\frac{C_{t}}{C_{o}-C_{t}}\right)=K_{Y N} t-\tau K_{Y N}
$$

where $\mathrm{K}_{\mathrm{YN}}\left(\mathrm{min}^{-1}\right)$ is the Yoon-Nelson rate constant, $\tau(\mathrm{min})$ is the required time for $50 \%$ of the phosphate breakthrough and $t(\mathrm{~min})$ is the running time. The values of $K_{Y N}$ and $\tau$ can be obtained from the linear plot of $\ln \left(\frac{C_{t}}{C_{0}-C_{t}}\right)$ vs. $t$ using the slope and intercept respectively.

\section{Results and Discussions}

\subsection{Adsorbent Characterization}

The FT-IR spectrum of the adsorbent material (leftover coal) at wavelengths ranging from 5000 to $450 \mathrm{~cm}^{-1}$ is shown in Figure 1. Five major bands were identified for the FT-IR spectrum of the coal material, from which a strong and broad band was formed due the stretching vibration of-OH functional groups at the wave number of $3694.15 \mathrm{~cm}^{-1}$; the band around $1631.96 \mathrm{~cm}^{-1}$ indicated the bending vibration of $-\mathrm{NH}$ in $\mathrm{NH}_{2}$ for the FT-IR spectrum of coal materials [53,54]. The band obtained at the wave number of $2931.82 \mathrm{~cm}^{-1}$ indicated stretching vibrations of $\mathrm{C}-\mathrm{H}[55,56]$. The peak observed in FT-IR spectrum band at $1358.20 \mathrm{~cm}^{-1}$ for coal material is characteristic of the $\mathrm{SiO}_{4}{ }^{-2}$ group, and is caused by the symmetric stretching vibration of $\mathrm{Si}-\mathrm{O}-\mathrm{Si}$ and the stretching vibration of $-\mathrm{CO}$ in $-\mathrm{COH}[53,54,57]$. The small peaks shown at the bands of 537.92 and $471.98 \mathrm{~cm}^{-1}$ in the FT-IR spectrum of the leftover coal material belong to the bending vibration of $\mathrm{Si}-\mathrm{O}-\mathrm{Si}$ bonds $[43,58]$. As shown in Figure 1b, after column adsorption, some weak bands occurred at the band wavelengths of 537 and $471 \mathrm{~cm}^{-1}$. This shows the adsorption of phosphate onto the surface of the adsorbent $[46,59]$.

The XRD pattern of the leftover coal material before and after column adsorption is presented in Figure 2. A diffraction peak at $2 \theta=12.6$ degree is associated with kaolinite $\left(\mathrm{Al}_{2} \mathrm{O}_{3} 2 \mathrm{SiO}_{2} \cdot 2 \mathrm{H}_{2} \mathrm{O}\right)$, and the typical peak obtained at $2 \theta=25.4$ degrees was induced by quartz $\left(\mathrm{SiO}_{2}\right)$. The small peak at $2 \theta=35$ degrees belongs to goethite, consisting of iron (III) oxide-hydroxide [27,60]. Data for coal material obtained from XRD patters revealed the dominance of $\mathrm{Si}$ in coal material, which agrees with obtained SEM/EDX data from our previous work [31]. The crystalline size of the XRD pattern of the coal martial can be calculated from the Scherer equation as presented in Equation (11).

$$
D=\frac{\mathrm{K} \lambda}{\beta \cos \theta}
$$

where $D$ is the average crystalline size (nm), K crystal shape factor or Scherer constant ( 0.68 to 2.08 and 0.94 for spherical crystallites with cubic symmetry) [61], $\lambda$ is $\mathrm{X}$-ray wavelength of radiation which is for Cuk $\alpha=1.4 \AA$, $\beta$ peak breadth or line broadening at full width at half maximum (FWHM) in radian, and $\theta$ is equal to $\frac{1}{2}$ of the $2 \theta$ position of the peak. The crystalline of the leftover coal material was $6.2 \mathrm{~nm}$. However, the XRD peaks of the coal material showed amorphous rather than crystalline surface; the more amorphous the surface was, the higher the adsorption capacity $[27,62]$.

\subsection{Effects of Operational Parameters}

\subsubsection{Effects of Adsorbent Bed Height}

The effect of bed heights on the breakthrough curves of column adsorption were studied using bed heights of 5,6 , and $8 \mathrm{~cm}$ with a constant influent phosphate concentration of $10 \mathrm{mg} / \mathrm{L}$ and at a fixed flow rate of $1 \mathrm{~mL} / \mathrm{min}$. Figure 3 shows the related breakthrough curves with different bed heights. The removal efficiency of the phosphate was proportional to the proposed bed height. In all cases, breakthrough times were extended from 190 to 
$235 \mathrm{~min}$, and then to $348 \mathrm{~min}$, with increasing bed height from 5 to $8 \mathrm{~cm}$. Subsequently, the influent volume of phosphate solution treated at the breakthrough time $\left(\mathrm{V}_{\mathrm{i}}\right)$ and at exhaustion time $\left(\mathrm{V}_{\mathrm{e}}\right)$ increased from 190 to $348 \mathrm{~mL}$ and from 273 to $381 \mathrm{~mL}$, respectively, for longer bed heights as compared with for the shorter one (Table 1). This indicates that the shorter beds saturated faster than the longer one did because the longer bed heights need longer to become saturated [18]. The increase in Vi and Ve was probably due to the high contact time between phosphate ions and adsorbent [19]. Furthermore, the longer bed height $(8 \mathrm{~cm})$ used in this study had higher phosphate adsorption capacity $(190.7 \mathrm{mg} / \mathrm{kg})$ than that of $6 \mathrm{~cm}(178 \mathrm{mg} / \mathrm{kg})$ and $5 \mathrm{~cm}(163 \mathrm{mg} / \mathrm{kg})$ bed height. Therefore, the longer the bed height was, the longer the time taken was to reach complete exhaustion time due to broadened mass transfer zone for phosphate adsorption [47,48].

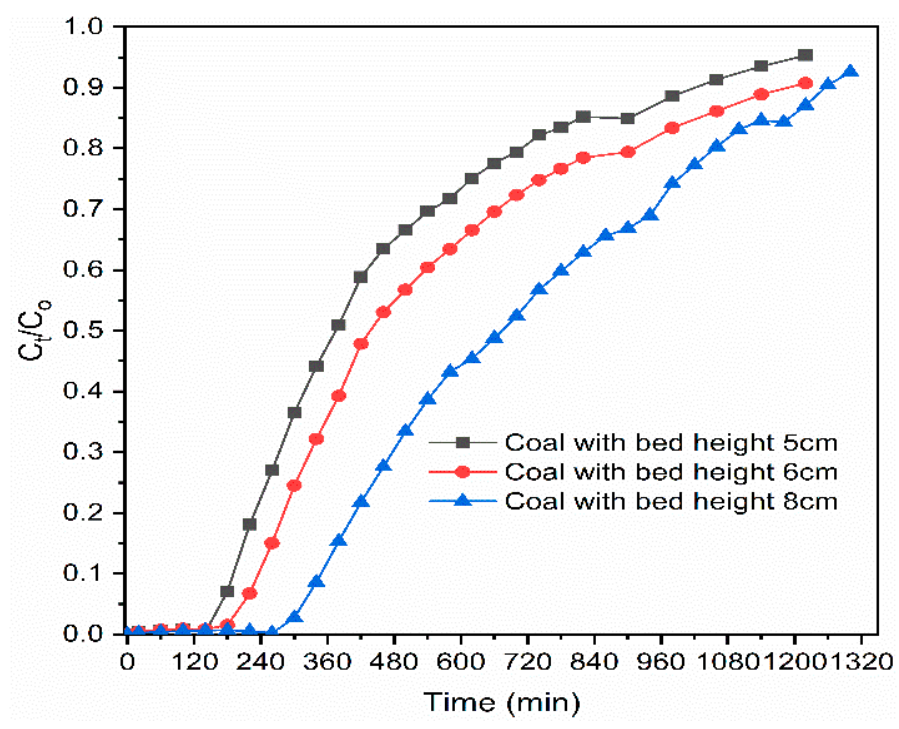

Figure 3. Effect of adsorbent bed height on phosphate breakthrough.

Table 1. Obtained parameters from breakthrough curves for phosphate adsorption onto leftover coal material with different bed heights, initial phosphate concentrations, and flow rates.

\begin{tabular}{ccccccccccc}
\hline $\begin{array}{c}\mathbf{C}_{\mathbf{o}} \\
(\mathbf{m g} / \mathbf{L})\end{array}$ & $\begin{array}{c}\mathbf{H}_{\mathbf{b}} \\
(\mathbf{c m})\end{array}$ & $\begin{array}{c}\mathbf{Q} \\
(\mathbf{m L} / \mathbf{m i n})(\mathbf{m L})\end{array}$ & $\begin{array}{c}\mathbf{V}_{\mathbf{i}} \\
(\mathbf{m i n})\end{array}$ & $\begin{array}{c}\mathbf{t}_{\mathbf{e}} \\
(\mathbf{m i n})\end{array}$ & $\begin{array}{c}\mathbf{E B C T} \\
(\mathbf{m i n})\end{array}$ & $\begin{array}{c}\mathbf{M T Z} \\
(\mathbf{c m})\end{array}$ & $\begin{array}{c}\mathbf{q}_{\text {total }} \\
(\mathbf{m g})\end{array}$ & $\begin{array}{c}\mathbf{q} \mathbf{e} \\
(\mathbf{m g} / \mathbf{k g})\end{array}$ & $\begin{array}{c}\mathbf{V}_{\mathbf{e}} \\
(\mathbf{m L})\end{array}$ \\
\hline 10 & 8 & 1 & 348.39 & 348.39 & 381.37 & 607.79 & 5.78 & 5.72 & 190.70 & 381.37 \\
10 & 8 & 2 & 374.06 & 187.03 & 313.39 & 303.89 & 6.56 & 6.27 & 208.90 & 626.78 \\
10 & 5 & 1 & 190.68 & 190.68 & 273.21 & 257.33 & 3.96 & 4.10 & 163.90 & 273.21 \\
10 & 6 & 1 & 235.73 & 235.73 & 297 & 357.81 & 4.59 & 4.46 & 178.20 & 297 \\
10 & 8 & 1 & 348.39 & 348.39 & 381.37 & 607.79 & 5.78 & 5.72 & 190.70 & 381.37 \\
10 & 8 & 1 & 348.39 & 348.39 & 381.37 & 607.79 & 5.78 & 5.72 & 190.70 & 381.37 \\
25 & 8 & 1 & 144.45 & 144.45 & 291.92 & 607.79 & 6.96 & 7.30 & 243.20 & 291.79 \\
\hline
\end{tabular}

\subsubsection{Effects of Influent Concentrations}

The effect of initial phosphate concentration on the performance of the column was studied by varying the inlet concentration from 10 to $25 \mathrm{mg} / \mathrm{L}$ while the same adsorbent bed height of $8 \mathrm{~cm}$ and flow rate of $1 \mathrm{~mL} / \mathrm{min}$ were used. Figure 4 shows that a very fast breakthrough time occurred at the inlet concentration of $25 \mathrm{mg} / \mathrm{L}$. At a higher influent concentration of the phosphate, the quick fill of the binding sites of the adsorbent material was observed [41,63]. As the influent phosphate concentration increased from 10 to $25 \mathrm{mg} / \mathrm{L}$, exhaustion time also decreased from 348 to $144 \mathrm{~min}$. The lower phosphate concentration caused the slower diffusion of the phosphate than that of the higher concentration onto the surface of the coal material due to the lower mass transfer coefficient, and contributed 
to the longer breakthrough time and exhaustion time [18,41]. Equally, the higher the influent concentration was, the higher the concentration gradient and the lower the mass resistance were with shorter breakthrough time and exhaustion time. Similar tendencies were reported by [64] in the case of removing phosphate from an aqueous solution using zirconium-loaded okara. Nevertheless, the increase in influent concentration increased the phosphate removal capacity (from 190 to $243 \mathrm{mg} / \mathrm{kg}$ ), but the total influent volume (Vi) of the treated solution was decreased from 348 to $144 \mathrm{~mL}$. Utilizing the lower influent phosphate concentration is preferable to a higher concentration when the treatment of a larger volume is prioritized. Calculated parameters for different concentrations are presented in Table 1.

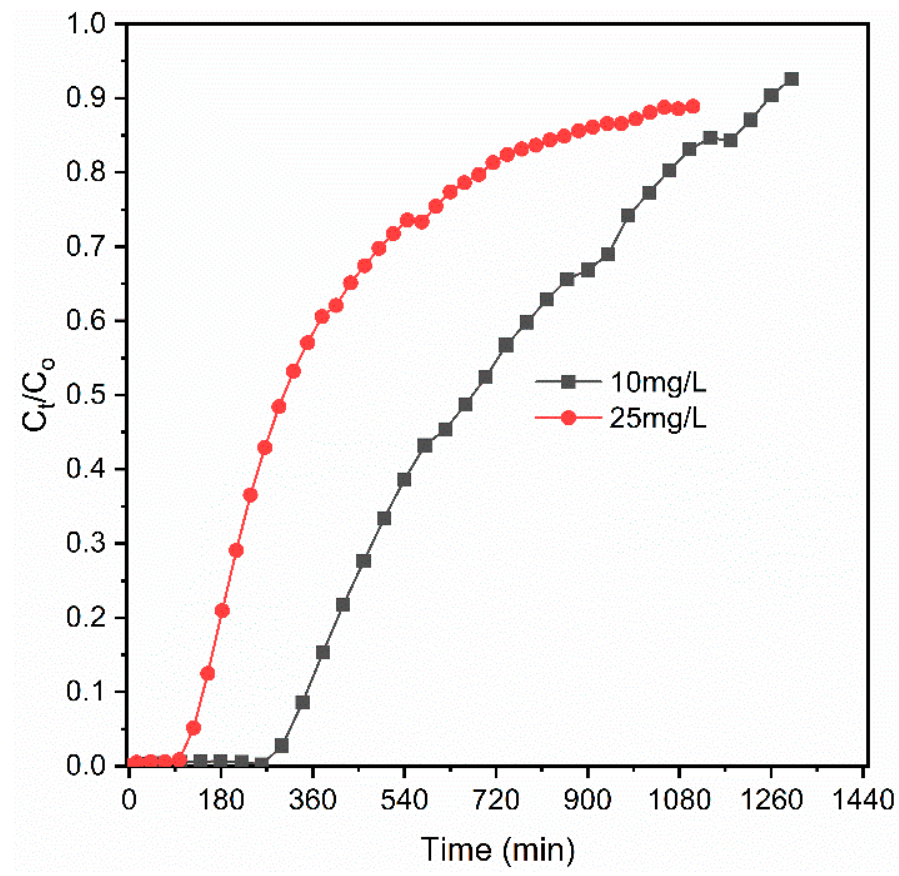

Figure 4. Effect of influent concentration on phosphate behaviors.

\subsubsection{Effects of Influent Flow Rate}

The breakthrough curves at different flow rates $(1$ and $2 \mathrm{~mL} / \mathrm{min})$ using influent phosphate concentration of $10 \mathrm{mg} / \mathrm{L}$ and adsorbent bed height of $8 \mathrm{~cm}$ are presented in Figure 5. The breakthrough time and exhaustion time of the adsorbent material appeared significantly faster, which was related to the mass transfer process when the used flow rates were increased from 1 to $2 \mathrm{~mL} / \mathrm{min}$. In this case, the breakthrough time decreased from 348 to $187 \mathrm{~min}$, and exhaustion time decreased from 381 to $313 \mathrm{~min}$ for the increase in flow rate from 1 to $2 \mathrm{~mL} / \mathrm{min}$. Another study reported a very fast breakthrough time $(<40 \mathrm{~min})$ for the removal of phosphate from a solution using andosol bagasse mixtures at the influent solution flow rate of $4 \mathrm{~mL} / \mathrm{min}$ in $1.8 \mathrm{~cm}$ bed height [19]. According to Chittoo and Sutherland (2020) [65], increasing the flow rate may reduce the resident time of the adsorbate to diffuse into the pores of the adsorbent materials; thus, the adsorbates predominately interact with surface functional groups. At lower flow rates, adsorbates have enough time to interact with the surface of the adsorbents, and additional external mass transfer and intraparticle diffusion are thus enhanced [66], where, at the higher flow rate, the adsorbate solution leaves the column before reaching the equilibrium point [67]. The adsorption parameters for varying bed depths, concentrations, and flow rates are presented in Table 1. 


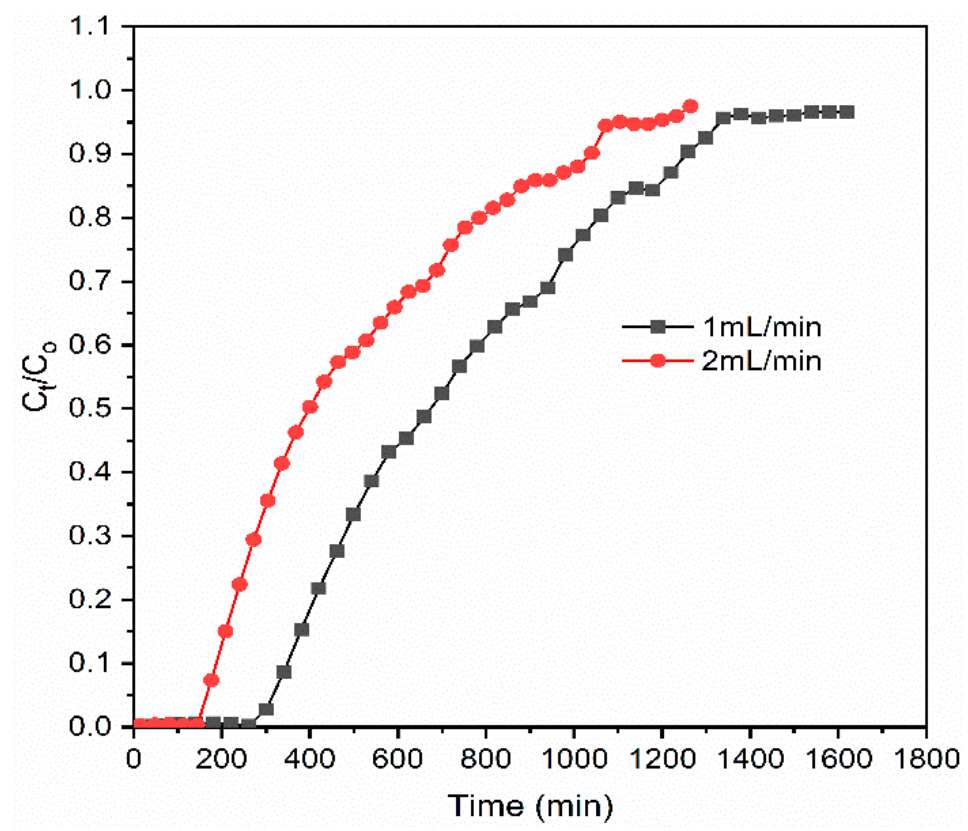

Figure 5. Effect of influent flow rate on phosphate breakthrough.

\subsection{Prediction of Breakthrough Curves Using Adsorption Models}

Predicting fixed-bed column parameters in continuous flow analysis is very important for both laboratory- and industrial-scale processes [15]. The breakthrough curve is a plot of ratios of effluent to influent concentrations versus running time, and its prediction provides the mechanisms and generally any changes in the adsorption processes. In the present study, three theoretical models, namely, the Thomas, Adams-Bohart, and Yoon-Nelson models, were applied to determine the best model for predicting the dynamic behaviors of the models $[68,69]$.

The Thomas model is frequently used to determine adsorption capacity of the adsorbent. The rate constant, adsorption capacity, and other parameters were obtained from the linear plot of Equation (8) and numerical values are presented in Table 2. Table 2 shows that $K_{\mathrm{Th}}$ values increased from $1.67 \times 10^{2}$ to $2.83 \times 10^{2} \mathrm{~mL} / \mathrm{min} \mathrm{mg}$, while the values of $\mathrm{q}_{\mathrm{Th}}$ decreased from 328 to $203 \mathrm{mg} / \mathrm{kg}$ with increasing adsorbent bed height from 5 to $8 \mathrm{~cm}$. However, other researchers reported a decreasing value of $K_{T h}$ and increase in $q_{T h}$ with increasing bed depth. This is may have been due to the experimental measuring and applying different adsorbents. On the other hand, the values of $\mathrm{K}_{\mathrm{Th}}$ decreased with increasing influent phosphate concentration and flow rate. These values can be illustrated with the driving force due to the increase in concentration gradients and flow rate as reported in other studies $[19,32]$. Regression values $\left(R^{2}\right)$ from the Thomas model ranged from 0.84 to 0.94 , which illustrated a worse fit than that of other models.

The calculated data for the Adams-Bohart model are presented in Table 2. $\mathrm{K}_{\mathrm{AB}}$ values increased with increasing adsorbent bed height, but decreased with increasing influent phosphate concentration and flow rate. The values of No decreased with increasing bed height and influent phosphate concentration, but increased with increasing flow rate. The calculated and experimental data for the A-B model using initial phosphate concentration and adsorbent bed height are illustrated in Figures 6 and 7, where the $R^{2}$ values of A-B model ranged in between 0.92 to 0.98 , which provided a better fit than that of the Thomas and $\mathrm{Y}-\mathrm{N}$ models. 
Table 2. Parameters for Thomas, Adam-Bohart, and Yoon-Nelson models at different parameters.

\begin{tabular}{|c|c|c|c|c|c|c|c|c|c|c|c|c|}
\hline \multirow{2}{*}{$\begin{array}{c}\text { Exp. } \\
\text { Parameters }\end{array}$} & \multirow[b]{2}{*}{$\underset{(\mathrm{mg} / \mathrm{L})}{\text { Co }}$} & \multirow[b]{2}{*}{$\begin{array}{l}\mathrm{H}_{\mathrm{b}} \\
(\mathrm{cm})\end{array}$} & \multirow[b]{2}{*}{$\underset{(\mathrm{mL} / \mathrm{min})}{\mathrm{Q}}$} & \multicolumn{3}{|c|}{ Thomas } & \multicolumn{3}{|c|}{ Adams-Bohart } & \multicolumn{3}{|c|}{ Yoon-Nelson } \\
\hline & & & & $\underset{(\mathrm{mL} / \mathrm{min} . \mathrm{mg})}{\mathrm{K}_{\mathrm{Th}} \times 10^{2}}$ & $\underset{(\mathrm{mg} / \mathrm{g})}{\mathrm{q}_{\mathrm{Th}}}$ & $\mathbf{R}^{2}$ & $\begin{array}{l}\mathrm{K}_{\mathrm{AB}} \times 10^{3} \\
(\mathrm{~L} / \mathrm{mg} \mathrm{min})\end{array}$ & $\begin{array}{c}\mathrm{N}_{\mathrm{o}} \times 10^{3} \\
(\mathrm{mg} / \mathrm{L})\end{array}$ & $\mathbf{R}^{2}$ & $\underset{\left(\min ^{-1}\right)}{\mathrm{K}_{\mathrm{YN}}}$ & $\tau(\min )$ & $\mathbf{R}^{2}$ \\
\hline \multirow{3}{*}{$\mathrm{Q}(\mathrm{mL} / \mathrm{min})$} & 10 & 8 & 1 & 2.830 & 0.215 & 0.87 & 0.188 & 1.690 & 0.98 & 2.831 & 6.453 & 0.90 \\
\hline & 10 & 8 & 2 & 2.610 & 0.203 & 0.92 & 0.172 & 3.217 & 0.92 & 2.613 & 6.079 & 0.92 \\
\hline & 10 & 5 & 1 & 1.670 & 0.328 & 0.84 & 0.151 & 2.602 & 0.96 & 2.608 & 5.985 & 0.92 \\
\hline \multirow[t]{2}{*}{$\mathrm{H}_{\mathrm{b}}(\mathrm{cm})$} & 10 & 6 & 1 & 2.430 & 0.253 & 0.93 & 0.155 & 2.188 & 0.98 & 2.430 & 6.174 & 0.93 \\
\hline & 10 & 8 & 1 & 2.830 & 0.215 & 0.87 & 0.188 & 1.690 & 0.98 & 2.831 & 6.453 & 0.90 \\
\hline \multirow{2}{*}{$\mathrm{C}_{\mathrm{o}}(\mathrm{mg} / \mathrm{L})$} & 10 & 8 & 1 & 2.830 & 0.215 & 0.87 & 0.188 & 1.690 & 0.98 & 2.831 & 6.453 & 0.90 \\
\hline & 25 & 8 & 1 & 2.120 & 0.197 & 0.94 & 0.143 & 1.578 & 0.92 & 2.121 & 5.908 & 0.94 \\
\hline
\end{tabular}

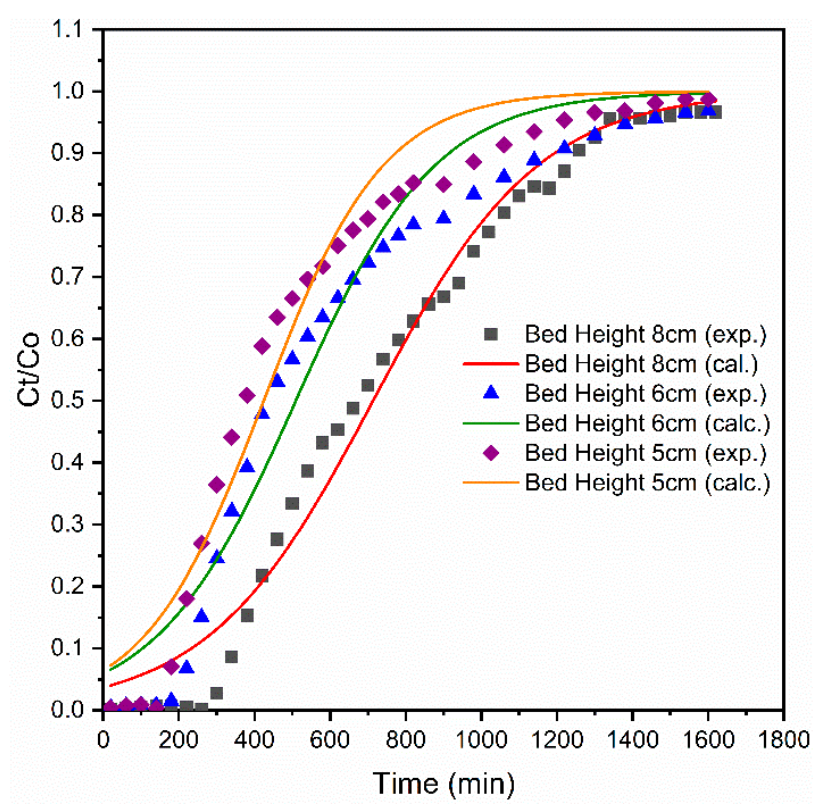

Figure 6. Experimental and calculated breakthrough curve for Adams-Bohart model at different values of adsorbent bed height.

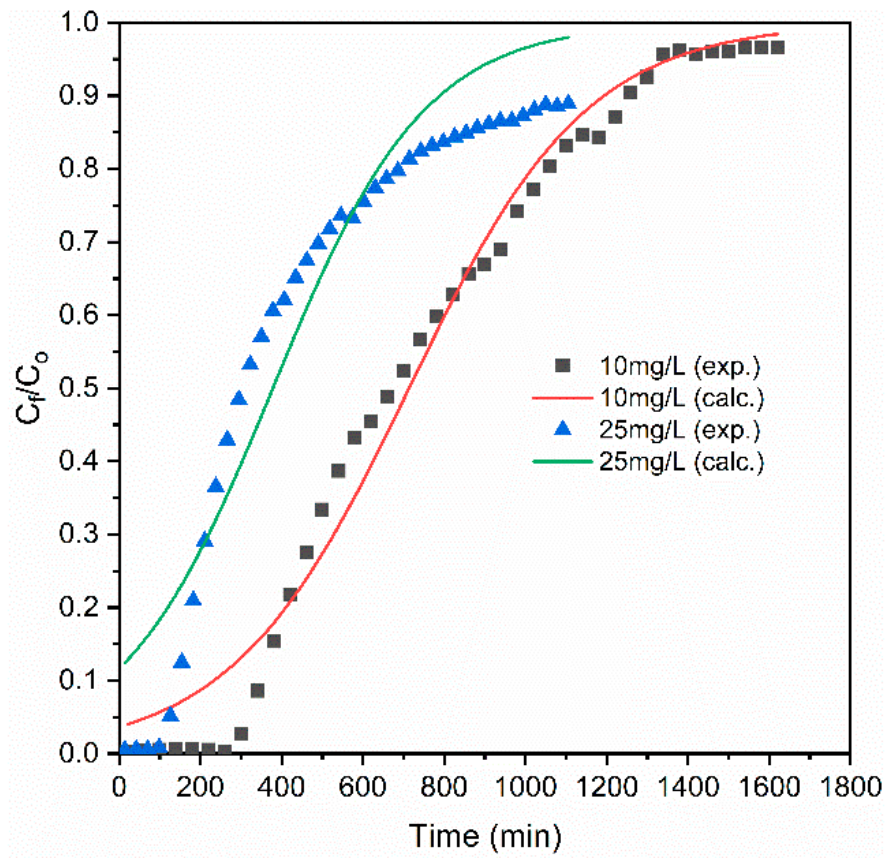

Figure 7. Experimental and calculated breakthrough curve values for Adams-Bohart model at different values of influent phosphate concentration. 
The Yoon-Nelson (N-Y) rate constant, $\mathrm{K}_{\mathrm{YN}}$, and time required for $50 \%$ breakthrough $\tau$ values at different operational parameters are presented in Table 2 . The values of both $\mathrm{K}_{\mathrm{YN}}$ and $\tau$ were decreased with increasing flow rate and influent phosphate concentration. The fitness of the $\mathrm{N}-\mathrm{Y}$ model was evaluated using correlation values $\left(\mathrm{R}^{2}\right)$ ranging from 0.90 to 0.94 . The $\mathrm{Y}-\mathrm{N}$ model described the behavior of sorption of phosphate better than the Thomas model did under different experimental conditions. However, the Adams-Bohart model described the adsorption of the phosphate in the column better than the Thomas and Y-N models did at different operational conditions.

\section{Conclusions}

This study was conducted to test leftover coal as a material for the removal of phosphate from solutions by adsorption using continuous-flow fixed-bed column experiments. The adsorption performance and the breakthrough-curve characteristics of the column were influenced by influent phosphate concentration, adsorbent bed height, and the influent flow rate of the solution. The increase in bed height significantly improved the performance of the column by increasing the breakthrough and exhaustion times of the process, and increased the volume of water that could be treated. On the other hand, the increase in initial phosphate concentration and influent flow rate reduced the breakthrough and exhaustion times. This was due to the fast saturation of the surface of the adsorbent with phosphate ions and a lower resident time of the adsorbate. Adam-Bohart model fitted the experimental data well, and performed better than the Thomas and Yoon-Nelson adsorption models did. Overall, the results of this study suggest that phosphate removal using leftover coal material is a promising low-cost technology for the sustainable control of excess phosphate in water. However, additional testing of the adsorbent using surface modification and applying real sample water with competitive anions are required for final conclusions.

Author Contributions: Conceptualization, D.T.M., E.A., and B.L.; methodology, D.T.M.; formal analysis, D.T.M.; investigation, D.T.M., E.A., and B.L.; resources, E.A. and B.L.; data curation, D.T.M.; writing — original draft preparation, D.T.M.; writing—review and editing, E.A. and B.L.; supervision, E.A. and B.L. All authors have read and agreed to the published version of the manuscript.

Funding: This research received no external funding.

Institutional Review Board Statement: Not applicable.

Informed Consent Statement: Not applicable.

Data Availability Statement: The data used in this study are available from the first author upon request.

Acknowledgments: Acknowledgment goes to German Academic exchange Service (DAAD), University of Rostock, and Jimma University Institute of Technology for providing supports and scholarship during the study for the first author.

Conflicts of Interest: The authors declare no conflict of interest.

\section{References}

1. Nagoya, S.; Nakamichi, S.; Kawase, Y. Mechanisms of Phosphate Removal from Aqueous Solution by Zero-Valent Iron: A Novel Kinetic Model for Electrostatic Adsorption, Surface Complexation and Precipitation of Phosphate under Oxic Conditions. Sep. Purif. Technol. 2019, 218, 120-129. [CrossRef]

2. Ajmal, Z.; Muhmood, A.; Usman, M.; Kizito, S.; Lu, J.; Dong, R.; Wu, S. Phosphate Removal from Aqueous Solution Using Iron Oxides: Adsorption, Desorption and Regeneration Characteristics. J. Colloid Interface Sci. 2018, 525, 145-155. [CrossRef] [PubMed]

3. Hamzah, S.; Razali, N.A.; Yatim, N.I.; Alias, M.; Ali, A.; Zaini, N.S.; Abuhabib, A.A.M. Characterisation and Performance of Thermally Treated Rice Husk as Efficient Adsorbent for Phosphate Removal. J. Water Supply Res. Technol.-AQUA 2018, 67, 766-778. [CrossRef]

4. Sellner, B.M.; Hua, G.; Ahiablame, L.M. Fixed Bed Column Evaluation of Phosphate Adsorption and Recovery from Aqueous Solutions Using Recycled Steel Byproducts. J. Environ. Manag. 2019, 233, 595-602. [CrossRef]

5. Biswas, B.K.; Inoue, K.; Ghimire, K.N.; Harada, H.; Ohto, K.; Kawakita, H. Removal and Recovery of Phosphorus from Water by Means of Adsorption onto Orange Waste Gel Loaded with Zirconium. Bioresour. Technol. 2008, 99, 8685-8690. [CrossRef] 
6. Khan, S.; Ishaq, M.; Ahmad, I.; Hussain, S.; Ullah, H. Evaluation of Coal as Adsorbent for Phosphate Removal. Arab. J. Geosci. 2013, 6, 1113-1117. [CrossRef]

7. Shahid, M.K.; Kim, Y.; Choi, Y. Magnetite Synthesis Using Iron Oxide Waste and Its Application for Phosphate Adsorption with Column and Batch Reactors. Chem. Eng. Res. Des. 2019, 148, 169-179. [CrossRef]

8. Lin, K.Y.A.; Chen, S.Y.; Jochems, A.P. Zirconium-Based Metal Organic Frameworks: Highly Selective Adsorbents for Removal of Phosphate from Water and Urine. Mater. Chem. Phys. 2015, 160, 168-176. [CrossRef]

9. Hu, A.; Ren, G.; Che, J.; Guo, Y.; Ye, J.; Zhou, S. Phosphate Recovery with Granular Acid-Activated Neutralized Red Mud: Fixed-Bed Column Performance and Breakthrough Curve Modelling. J. Environ. Sci. 2020, 90, 78-86. [CrossRef]

10. Ramirez, A.; Giraldo, S.; García-Nunez, J.; Flórez, E.; Acelas, N. Phosphate Removal from Water Using a Hybrid Material in a Fixed-Bed Column. J. Water Process. Eng. 2018, 26, 131-137. [CrossRef]

11. Zhang, L.; Wan, L.; Chang, N.; Liu, J.; Duan, C.; Zhou, Q.; Li, X.; Wang, X. Removal of Phosphate from Water by Activated Carbon Fiber Loaded with Lanthanum Oxide. J. Hazard. Mater. 2011, 190, 848-855. [CrossRef]

12. Đuričić, T.; Malinović, B.N.; Bijelić, D. The Phosphate Removal Efficiency Electrocoagulation Wastewater Using Iron and Aluminum Electrodes. Bull. Chem. Technol. Bosnia Herzeg. 2016, 47, 33-38.

13. Qiu, B.; Duan, F. Synthesis of Industrial Solid Wastes/Biochar Composites and Their Use for Adsorption of Phosphate: From Surface Properties to Sorption Mechanism. Colloids Surf. A Physicochem. Eng. Asp. 2019, 571, 86-93. [CrossRef]

14. Wang, S.; Kong, L.; Long, J.; Su, M.; Diao, Z.; Chang, X.; Chen, D.; Song, G.; Shih, K. Adsorption of Phosphorus by Calcium-Flour Biochar: Isotherm, Kinetic and Transformation Studies. Chemosphere 2018, 195, 666-672. [CrossRef]

15. Ye, Y.; Jiao, J.; Kang, D.; Jiang, W.; Kang, J.; Ngo, H.H.; Guo, W.; Liu, Y. The Adsorption of Phosphate Using a Magnesia-Pullulan Composite: Kinetics, Equilibrium, and Column Tests. Environ. Sci. Pollut. Res. 2019, 26, 13299-13310. [CrossRef]

16. Castro, D.; Rosas-Laverde, N.M.; Aldás, M.B.; Almeida-Naranjo, C.E.; Guerrero, V.H.; Pruna, A.I. Chemical Modification of Agro-Industrial Waste-Based Bioadsorbents for Enhanced Removal of Zn(Ii) Ions from Aqueous Solutions. Materials 2021, 14, 2134. [CrossRef]

17. Bezza, F.A.; Chirwa, E.M.N. Removal of Phosphate from Contaminated Water Using Activated Carbon Supported Nanoscale Zero-Valent Iron (NZVI) Particles. Chem. Eng. Trans. 2021, 84, 55-60. [CrossRef]

18. Rout, P.R.; Dash, R.R.; Bhunia, P. Modelling and Packed Bed Column Studies on Adsorptive Removal of Phosphate from Aqueous Solutions by a Mixture of Ground Burnt Patties and Red Soil. Adv. Environ. Res. 2014, 3, 231-251. [CrossRef]

19. Woumfo, E.D.; Siéwé, J.M.; Njopwouo, D. A Fixed-Bed Column for Phosphate Removal from Aqueous Solutions Using an Andosol-Bagasse Mixture. J. Environ. Manag. 2015, 151, 450-460. [CrossRef]

20. Jung, K.W.; Jeong, T.U.; Choi, J.W.; Ahn, K.H.; Lee, S.H. Adsorption of Phosphate from Aqueous Solution Using Electrochemically Modified Biochar Calcium-Alginate Beads: Batch and Fixed-Bed Column Performance. Bioresour. Technol. 2017, $244,23-32$. [CrossRef]

21. Andre, Y.; Barca, C.; Ge, C.; Meyer, D.; Chazarenc, F.; Andrès, Y. Phosphate Removal from Synthetic and Real Wastewater Using Steel Slags Produced in Europe. Water Res. 2012, 26, 2376-2384. [CrossRef]

22. Mekonnen, D.T.; Alemayehu, E.; Lennartz, B. Adsorptive Removal of Phosphate from Aqueous Solutions Using Low-Cost Volcanic Rocks: Kinetics and Equilibrium Approaches. Materials 2021, 14, 1312. [CrossRef]

23. Beji, R.; Hamdi, W.; Kesraoui, A.; Seffen, M. Adsorption of Phosphorus by Alkaline Tunisian Soil in a Fixed Bed Column. Water Sci. Technol. 2018, 78, 751-763. [CrossRef]

24. Cui, X.; Li, H.; Yao, Z.; Shen, Y.; He, Z.; Yang, X.; Ng, H.Y.; Wang, C.H. Removal of Nitrate and Phosphate by Chitosan Composited Beads Derived from Crude Oil Refinery Waste: Sorption and Cost-Benefit Analysis. J. Clean. Prod. 2019, 207, 846-856. [CrossRef]

25. Yang, Y.; Zhao, Y.Q.; Babatunde, A.O.; Wang, L.; Ren, Y.X.; Han, Y. Characteristics and Mechanisms of Phosphate Adsorption on Dewatered Alum Sludge. Sep. Purif. Technol. 2006, 51, 193-200. [CrossRef]

26. Xue, Y.; Hou, H.; Zhu, S. Characteristics and Mechanisms of Phosphate Adsorption onto Basic Oxygen Furnace Slag. J. Hazard. Mater. 2009, 162, 973-980. [CrossRef]

27. William, G.; Eren, Y.; Ayd, S.; Emik, S.; Tuba, A.; Osra, F.; Wasswa, J. A Facile Polymerisation of Magnetic Coal to Enhanced Phosphate Removal from Solution. J. Environ. Manag. 2019, 247, 356-362. [CrossRef]

28. Huang, Y.; Lee, X.; Grattieri, M.; Macazo, F.C.; Cai, R.; Minteer, S.D. A Sustainable Adsorbent for Phosphate Removal: Modifying Multi-Walled Carbon Nanotubes with Chitosan. J. Mater. Sci. 2018, 53, 12641-12649. [CrossRef]

29. Zhang, W.; Bu, A.; Ji, Q.; Min, L.; Zhao, S.; Wang, Y.; Chen, J. P Ka-Directed Incorporation of Phosphonates into Mof-808 via Ligand Exchange: Stability and Adsorption Properties for Uranium. ACS Appl. Mater. Interfaces 2019, 11, 33931-33940. [CrossRef] [PubMed]

30. Jung, K.W.; Jeong, T.U.; Choi, B.H.; Jeong Kang, H.; Ahn, K.H. Phosphate Adsorption from Aqueous Solution by Laminaria Japonica-Derived Biochar-Calcium Alginate Beads in a Fixed-Bed Column: Experiments and Prediction of Breakthrough Curves. Environ. Prog. Sustain. Energy 2017, 33, 1-9. [CrossRef]

31. Mekonnen, D.T.; Alemayehu, E.; Lennartz, B. Removal of Phosphate Ions from Aqueous Solutions by Adsorption onto Leftover Coal. Water 2020, 12, 1381. [CrossRef]

32. Negrea, A.; Mihailescu, M.; Mosoarca, G.; Ciopec, M.; Duteanu, N.; Negrea, P.; Minzatu, V. Estimation on Fixed-Bed Column Parameters of Breakthrough Behaviors for Gold Recovery by Adsorption onto Modified/Functionalized Amberlite Xad7. Int. J. Environ. Res. Public Health 2020, 17, 6868. [CrossRef] [PubMed] 
33. Nuryadin, A.; Imai, T. Application of Amorphous Zirconium (Hydr)Oxide/MgFe Layered Double Hydroxides Composite in Fixed-Bed Column for Phosphate Removal from Water. Glob. J. Environ. Sci. Manag. 2021, 7, 485-502. [CrossRef]

34. Rao, R.A.K.; Rehman, F.; Kashifuddin, M. Removal of $\mathrm{Cr}(\mathrm{VI})$ from Electroplating Wastewater Using Fruit Peel of Leechi (Litchi Chinensis). Desalin. Water Treat. 2012, 49, 136-146. [CrossRef]

35. Jiang, D.; Chu, B.; Amano, Y.; Machida, M. Removal and Recovery of Phosphate from Water by Mg-Laden Biochar: Batch and Column Studies. Colloids Surf. A Physicochem. Eng. Asp. 2018, 558, 429-437. [CrossRef]

36. Alemu, A.; Lemma, B.; Gabbiye, N.; Tadele, M.; Teferi, M. Removal of Chromium (VI) from Aqueous Solution Using Vesicular Basalt: A Potential Low Cost Wastewater Treatment System. Heliyon 2018, 4, 1-22. [CrossRef]

37. Kilpimaa, S.; Runtti, H.; Kangas, T.; Lassi, U.; Kuokkanen, T. Physical Activation of Carbon Residue from Biomass Gasification: Novel Sorbent for the Removal of Phosphates and Nitrates from Aqueous Solution. J. Ind. Eng. Chem. 2014, 21, 1354-1364. [CrossRef]

38. Lee, C.G.; Kim, J.H.; Kang, J.K.; Kim, S.B.; Park, S.J.; Lee, S.H.; Choi, J.W. Comparative Analysis of Fixed-Bed Sorption Models Using Phosphate Breakthrough Curves in Slag Filter Media. Desalin. Water Treat. 2015, 55, 1-11. [CrossRef]

39. Alalwan, H.A.; Abbas, M.N.; Abudi, Z.N.; Alminshid, A.H. Adsorption of Thallium Ion $\left(\mathrm{Tl}^{+3}\right)$ from Aqueous Solutions by Rice Husk in a Fixed-Bed Column: Experiment and Prediction of Breakthrough Curves. Environ. Technol. Innov. 2018, 12, 1-13. [CrossRef]

40. Lalley, J.; Han, C.; Li, X.; Dionysiou, D.D.; Nadagouda, M.N. Phosphate Adsorption Using Modified Iron Oxide-Based Sorbents in Lake Water: Kinetics, Equilibrium, and Column Tests. Chem. Eng. J. 2016, 284, 1386-1396. [CrossRef]

41. Husein, D.Z.; Al-Radadi, T.; Danish, E.Y. Adsorption of Phosphate Using Alginate-/Zirconium-Grafted Newspaper Pellets: Fixed-Bed Column Study and Application. Arab. J. Sci. Eng. 2017, 42, 1399-1412. [CrossRef]

42. Vieira, M.L.G.; Pinheiro, C.P.; Silva, K.A.; Lutke, S.F.; Cadaval, T.R.S.A.; Dotto, G.; Pinto, L.A.d.A. Chitosan and CyanoguanidineCrosslinked Chitosan Coated Glass Beads and Its Application in Fixed Bed Adsorption. Chem. Eng. Commun. 2019, 206, 1474-1486. [CrossRef]

43. Geleta, W.S.; Alemayehu, E.; Lennartz, B. Volcanic Rock Materials for Defluoridation Ofwater in Fixed-Bed Column Systems. Molecules 2021, 26, 977. [CrossRef]

44. Golie, W.M.; Upadhyayula, S. Continuous Fixed-Bed Column Study for the Removal of Nitrate from Water Using Chitosan/Alumina Composite. J. Water Process. Eng. 2016, 12, 58-65. [CrossRef]

45. Yagub, M.T.; Sen, T.K.; Afroze, S.; Ang, H.M. Fixed-Bed Dynamic Column Adsorption Study of Methylene Blue (MB) onto Pine Cone. Desalin. Water Treat. 2015, 55, 1-14. [CrossRef]

46. Nunes, K.G.P.; Batistel, N.R.; Barbosa, D.; Rosa, I.R.; Davila, I.V.J.; Féris, L.A. Adsorption of Hexavalent Chromium on a Coal Beneficiation Tailing Material in Batch and Fixed-Bed Column. Acta Bras. 2020, 4, 121-127. [CrossRef]

47. Tamez Uddin, M.; Rukanuzzaman, M.; Maksudur Rahman Khan, M.; Akhtarul Islam, M. Adsorption of Methylene Blue from Aqueous Solution by Jackfruit (Artocarpus heteropyllus) Leaf Powder: A Fixed-Bed Column Study. J. Environ. Manag. 2009, 90, 3443-3450. [CrossRef]

48. Li, N.; Ren, J.; Zhao, L.; Wang, Z.L. Fixed Bed Adsorption Study on Phosphate Removal Using Nanosized FeOOH-Modified Anion Resin. J. Nanomater. 2013, 2013, 1-6. [CrossRef]

49. Foo, K.Y.; Lee, L.K.; Hameed, B.H. Preparation of Tamarind Fruit Seed Activated Carbon by Microwave Heating for the Adsorptive Treatment of Landfill Leachate: A Laboratory Column Evaluation. Bioresour. Technol. 2013, 133, 599-605. [CrossRef]

50. Chu, K.H. Breakthrough Curve Analysis by Simplistic Models of Fixed Bed Adsorption: In Defense of the Century-Old BohartAdams Model. Chem. Eng. J. 2020, 380, 122513. [CrossRef]

51. Han, R.; Ding, D.; Xu, Y.; Zou, W.; Wang, Y.; Li, Y.; Zou, L. Use of Rice Husk for the Adsorption of Congo Red from Aqueous Solution in Column Mode. Bioresour. Technol. 2008, 99, 2938-2946. [CrossRef] [PubMed]

52. Aksu, Z.; Gönen, F. Biosorption of Phenol by Immobilized Activated Sludge in a Continuous Packed Bed: Prediction of Breakthrough Curves. Process. Biochem. 2004, 39, 599-613. [CrossRef]

53. Huang, Y.; Lee, X.; Grattieri, M.; Yuan, M.; Cai, R.; Macazo, F.C.; Minteer, S.D. Modified Biochar for Phosphate Adsorption in Environmentally Relevant Conditions. Chem. Eng. J. 2020, 380, 122375. [CrossRef]

54. Li, N.; Bai, R. A Novel Amine-Shielded Surface Cross-Linking of Chitosan Hydrogel Beads for Enhanced Metal Adsorption Performance. Ind. Eng. Chem. Res. 2005, 44, 6692-6700. [CrossRef]

55. Omari, H.; Dehbi, A.; Lammini, A.; Abdallaoui, A. Study of the Phosphorus Adsorption on the Sediments. J. Chem. 2019, 1-10. [CrossRef]

56. Liu, D.; Zhu, H.; Wu, K.; Wang, F.; Zhao, X.; Liao, Q. Understanding the Effect of Particle Size of Waste Concrete Powder on Phosphorus Removal Efficiency. Constr. Build. Mater. 2020, 236, 117526. [CrossRef]

57. Li, X.; Weihu, Y.; Zou, Q.; Zuo, Y. Investigation on Microstructure, Composition, and Cytocompatibility of Natural Pumice for Potential Biomedical Application. Tissue Eng.Part. C Methods 2010, 16, 427-434. [CrossRef]

58. Pirsaheb, M.; Mohammadi, H.; Sharafi, K.; Asadi, A. Fluoride and Nitrate Adsorption from Water by Fe(III)-Doped Scoria: Optimizing Using Response Surface Modeling, Kinetic and Equilibrium Study. Water Sci. Technol. Water Supply 2018, 18, 1117-1132. [CrossRef]

59. Xie, J.; Wang, Z.; Lu, S.; Wu, D.; Zhang, Z.; Kong, H. Removal and Recovery of Phosphate from Water by Lanthanum Hydroxide Materials. Chem. Eng. J. 2014, 254, 163-170. [CrossRef] 
60. Yuan, Y.; Zhang, H.; Pan, G. Flocculation of Cyanobacterial Cells Using Coal Fly Ash Modified Chitosan. Water Res. 2016, 97, 11-18. [CrossRef]

61. Langford, J.I.; Wilson, A.J.C. Scherrer after Sixty Years: A Survey and Some New Results in the Determination of Crystallite Size. J. Appl. Crystallogr. 1978, 11, 102-113. [CrossRef]

62. Yang, Q.; Wang, X.; Luo, W.; Sun, J.; Xu, Q.; Chen, F.; Zhao, J.; Wang, S.; Yao, F.; Wang, D.; et al. Effectiveness and Mechanisms of Phosphate Adsorption on Iron-Modified Biochars Derived from Waste Activated Sludge; Elsevier Ltd.: Amsterdam, The Netherlands, 2018; Volume 247, ISBN 8673188822829. [CrossRef]

63. Chowdhury, Z.Z.; Zain, S.M.; Rashid, A.K.; Rafique, R.F.; Khalid, K. Breakthrough Curve Analysis for Column Dynamics Sorption of Mn(II) Ions from Wastewater by Using Mangostana Garcinia Peel-Based Granular-Activated Carbon. J. Chem. 2013, 2013, 1-9. [CrossRef]

64. Nguyen, T.A.H.; Ngo, H.H.; Guo, W.S.; Pham, T.Q.; Li, F.M.; Nguyen, T.V.; Bui, X.T. Adsorption of Phosphate from Aqueous Solutions and Sewage Using Zirconium Loaded Okara (ZLO): Fixed-Bed Column Study. Sci. Total Environ. 2015, 523, 40-49. [CrossRef]

65. Chittoo, B.S.; Sutherland, C. Column Breakthrough Studies for the Removal and Recovery of Phosphate by Lime-Iron Sludge: Modeling and Optimization Using Artificial Neural Network and Adaptive Neuro-Fuzzy Inference System. Chin. J. Chem. Eng. 2020, 28, 1847-1859. [CrossRef]

66. Zheng, Y.; Wang, B.; Wester, A.E.; Chen, J.; He, F.; Chen, H.; Gao, B. Reclaiming Phosphorus from Secondary Treated Municipal Wastewater with Engineered Biochar. Chem. Eng. J. 2019, 362, 460-468. [CrossRef]

67. Babu, B.V.; Gupta, S. Modeling and Simulation of Fixed Bed Adsorption Column: Effect of Velocity Variation. i-Manag. J. Future Eng. Technol. 2005, 1, 60-66. [CrossRef]

68. Bohart, G.S.; Adams, E.Q. Some Aspects of the Behavior of Charcoal with Respect to Chlorine. J. Chem. Soc. 1920, 42, 523-544. [CrossRef]

69. Thomas, H.C. Hetrogeneous Ion Exchange in Flowing System. J. Am. Chem. Soc. 1944, 66, 1664-1666. [CrossRef] 